\title{
Effect of acidification of insecticide sprays in pest control of sugar beet seedlings
}

\author{
AnNa-LiIsa VARIS \\ University of Helsinki, Department of Agricultural and Forest Zoology
}

\begin{abstract}
The $\mathrm{pH}$ of dimethoate, formetanate and methidathion insecticide spray liquids was reduced from 8.0 to 4.0 by adding $0.1 \mathrm{M} \mathrm{H}_{3} \mathrm{PO}_{4}$. Acidification did not improve the effectiveness of sprays against Lygus rugulipennis, Chaetocnema concinna or Piesma maculatum. There were also no significant differences in root or top yields between plots treated with acidified insecticides and the incecticides alone.
\end{abstract}

The main pests of sugar beet seedlings in Finland are Lygus rugulipennis Popp. and Chaetocnema concinna Marsh. The latter is very satisfactorily controlled if necessary but control of Lygus bugs in sugar beet fields is often poor. Spraying with dimethoate prevents the damage to some extent and increases the yield (VARIS 1975, VARIS and RAUTAPÄ̈̈ 1976). Because some insecticides as e.g. formetanate and methidathion, as well as dimethoate, which is mostly used by the farmers for this purpose, are more quickly inactivated in alkaline than in acid spray waters (manufacturers' bulletins) the question whether the effect of some insecticides can be improved by acidification of sprays was studied in Tikkurila. In the studies of JoHANSEN and Eves (1972) acidification of trichlorfon and carbofuran sprays increased their effectiveness against lygus bugs.

\section{Material and methods}

Spray solutions. $0.15,0.25$ and 0.19 per centage solutions of $40 \%$ dimethoate spray (Roxion), $50 \%$ formetanate w.p. (Dicarzol $500 \mathrm{SP}$ ), and $40 \%$ methidathion spray (Ultracide 40 ), respectively, were prepared mixing the insecticides in local tap water. The $\mathrm{pH}$ 's of the solutions were ca. 7 when the $\mathrm{pH}$ curves were titrated (Fig.1). Acidified spraying solutions were prepared adding to these solutions $0.1 \mathrm{M}(1 \%)$ phosphoric acid until the $\mathrm{pH}$ of the solutions, controlled by $\mathrm{pH}$ meter, was 4 . There was some variation in the $\mathrm{pH}$ of tap water; when the $\mathrm{pH}$ curves were titrated for these tests the $\mathrm{pH}$ was 7.4 and the specific conductance $3 \times 10^{-4} \mathrm{mho} / \mathrm{cm} .10 \mathrm{ml}$ of $0.1 \mathrm{M}$ phosphoric acid in $300 \mathrm{ml}$ distilled water required $14.7 \mathrm{ml}$ of $0.1 \mathrm{~N} \mathrm{NaOH}$ when titrated to $\mathrm{pH} 7$. On the days when the sprays were applicated the $\mathrm{pH}$ was 


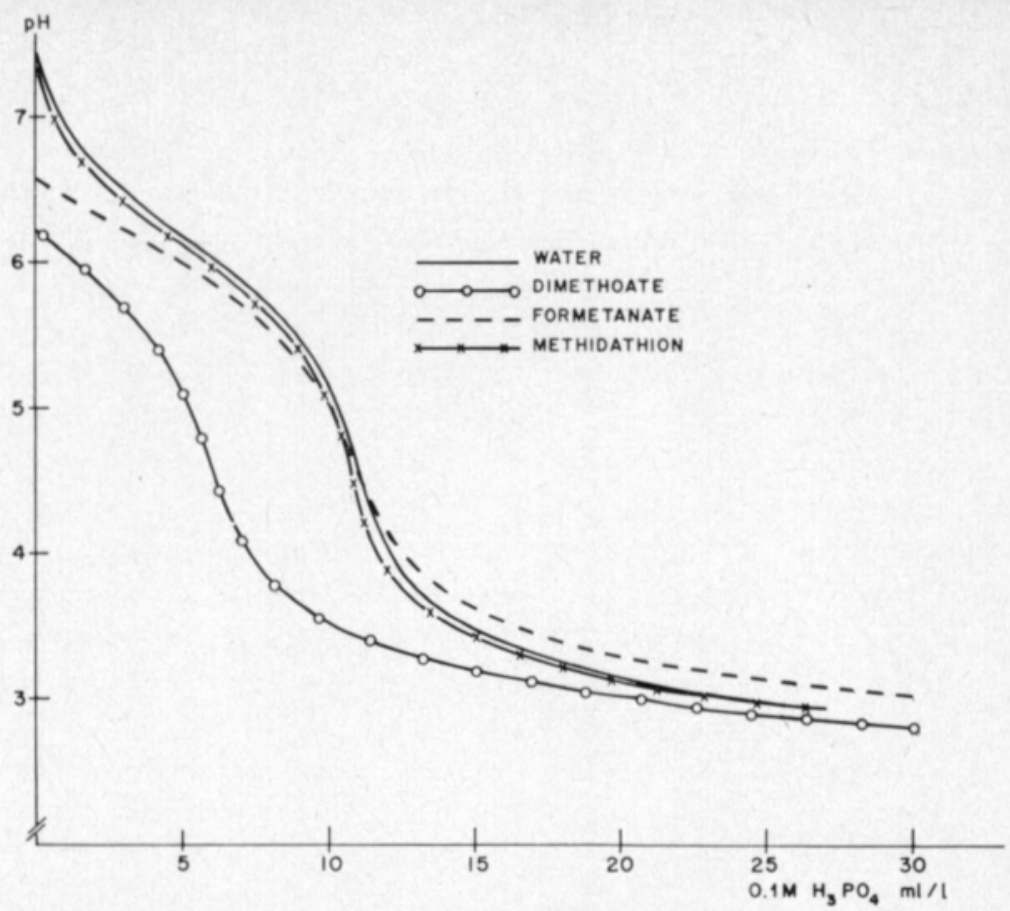

Fig. 1. The amount of $0.1 \mathrm{M} \mathrm{H}_{3} \mathrm{PO}_{4}$ needed for acid spray solutions. The pH-value of water was 7,4 and conductivity $2.85 \mathrm{mho} / \mathrm{cm}$.

8.0 (except in the laboratory test in 1974 when it was 7.2). This lead to slight variations in the amounts of $\mathrm{H}_{3} \mathrm{PO}_{4}$. The amount of $0.1 \mathrm{M} \mathrm{H}_{3} \mathrm{PO}_{4}$ needed was about equal for water, formetanate and methidathion spray solutions, but considerably smaller for dimethoate spray.

Laboratory tests. Sugar beet seedlings growing in pots $15 \mathrm{~cm}$ in diameter were treated with insecticides mentioned above. In each treatment both acidified insecticide and the insecticide alone were used. The amount of spray solution was $40 \mathrm{ml} / \mathrm{m}^{2}$. Untreated lygus bugs were released in PVC rearing cages placed over each pot approximately 4 hours after spraying. There were 10 pots with 10 plants in each treatment. 5 male and 5 female bugs were released in each pot. Two similarly arranged tests were conducted at an interval of two weeks in August 1973.

The mortality of the bugs was checked 3 days and injury to the plants 7 days after treatment. The percentage control was calculated by Abbot's formula.

Weather conditions were very different during the two tests. Mean temperature of six days following the treatment was $16.9^{\circ} \mathrm{C}$ in the first experiment while it was $9.4^{\circ} \mathrm{C}$ in the second one.

In 1974 a laboratory trial was arranged according to the same plan as in the previous year, however, without bugs. The purpose of this trial was to show whether acidification of spray liquids had any effect on the plants themselves. In this trial vigour of growth was estimated using a scale of $0-105$ and 14 days after treatment, the plants were weighed and the length of ther roots was measured 2 weeks after treatment. 
Field trials. Two similar polyfactor field trials were arranged in 1973. The seedlings were treated twice: 28.5. and 4.6. Both acidified insecticide and the insecticide alone were used in each treatment. The control plots were treated with acidified and nonacidified water, respectively. The amount of spray solution was $40 \mathrm{ml} / \mathrm{m}^{2}$. Plot size was $10 \mathrm{~m}^{2}$ and there were 4 replicates.

The experiments were inspected at the end of June for injury by L. rugulipennis and C. concinna. The number of piesmid eggs (cf. VARIS 1974) attached to the plants was also counted and the vigou of stands evaluated plot by plot using a scale $0-10$. In the autumn the plots were harvested, and the rotal plant-weight as well as the root weight were determined.

In 1974 a field test was arranged according to the same plan as in the previous year. In this test $0.5 \%$ ammonium sulphate was used as acidifier. The $\mathrm{pH}$ of rain water was 6.0 and that of sprays acidified with ammonium sulphate was 5.6. Thus the difference between the two acidity levels was very slight in this trial.

\section{Results and discussion}

Laboratory tests. The effect of insecticides on lygus bugs was slightly decreased by acidification (Tables 1 and 2). The effect of dimethoate and formetanate was somewhat better in test 1 (warm weather) than in test 2 (cold weather).

There was no significant difference between acidified and neutral sprays in regard to the root length $(\mathrm{F}=0.38$, Table 3$)$.

The interaction $\mathrm{pH} \times$ treatment was significant in plant weight $\left(\mathrm{F}=3.17^{*}\right.$, Table 3), which was higher in formetanate treatment when the spray liquid was neutral than in acidified sprays of the same treatment. This was also to

Table 1. Percentage control of Lygus rugulipennis on sugar beet seedlings treated with acidified (a) and non acidified (n) insecticide spray liquids 3 days after treatment. Laboratory tests.

\begin{tabular}{|c|c|c|c|c|c|c|}
\hline & \multicolumn{2}{|c|}{ Test 1} & \multicolumn{2}{|c|}{ Test 2} & \multicolumn{2}{|c|}{ Mean } \\
\hline & a & $\mathrm{n}$ & a & $\mathrm{n}$ & $\mathbf{a}$ & $\mathrm{n}$ \\
\hline Dimethoate ..................... & 89 & 98 & 79 & 90 & & \\
\hline Formetanate .................. & 52 & 60 & 42 & 47 & & \\
\hline Methidathion $\quad . \ldots \ldots \ldots \ldots \ldots$ & 96 & 100 & 99 & 98 & & \\
\hline Mean & 79 & 86 & 73 & 78 & 76 & 82 \\
\hline
\end{tabular}

Table 2. Injury $(0-10)$ caused by $L$. rugulipennis to sugar beet seedlings treated with acidified (a) and non acidified (n) insecticide spray liquids, 7 days after treatment. Laboratory tests.

\begin{tabular}{|c|c|c|c|c|c|c|}
\hline & \multicolumn{2}{|c|}{ Test 1} & \multicolumn{2}{|c|}{ Test 2} & \multicolumn{2}{|c|}{ Mean } \\
\hline & a & $\mathrm{n}$ & a & $\mathrm{n}$ & a & $\mathrm{n}$ \\
\hline Dimethoate ....................... & 5.9 & 5.6 & 5.5 & 5.3 & & \\
\hline Formetanate .................. & 6.8 & 4.6 & 5.1 & 5.4 & & \\
\hline Methidathion $\quad . . \ldots \ldots \ldots \ldots . . . . . .$. & 4.8 & 4.4 & 4.5 & 3.8 & & \\
\hline Mean & 5.8 & 4.9 & 5.0 & 4.8 & 5.4 & 4.8 \\
\hline
\end{tabular}


Table 3. Effect of acidification of spray liquids on sugar beet seedlings. $\mathrm{a}=$ acidified, $\mathrm{n}=$ non acidified.

\begin{tabular}{|c|c|c|c|c|c|c|c|c|}
\hline & \multicolumn{4}{|c|}{$\begin{array}{c}\text { Vigour of growth }(0-10), \\
\text { days after treatment }\end{array}$} & \multicolumn{2}{|c|}{$\begin{array}{l}\text { Root } \\
\text { length } \\
\mathrm{cm}\end{array}$} & \multicolumn{2}{|c|}{$\begin{array}{c}\text { Plant } \\
\text { weight } \\
\mathrm{g}\end{array}$} \\
\hline & a & $\mathrm{n}$ & a & $\mathrm{n}$ & a & $\mathrm{n}$ & a & $\mathrm{n}$ \\
\hline Control $\ldots . . . \ldots \ldots \ldots \ldots \ldots$ & 8.7 & 8.4 & 8.9 & 8.4 & 8.1 & 7.9 & 3.8 & 3.4 \\
\hline Dimethoate ................ & 7.9 & 8.2 & 8.0 & 8.5 & 8.8 & 7.9 & 3.3 & 3.5 \\
\hline Formetanate .............. & 7.4 & 8.1 & 7.2 & 8.0 & 6.9 & 7.9 & 2.6 & 3.2 \\
\hline Methidathion $\ldots \ldots \ldots \ldots . . . .$. & 8.5 & 7.3 & 8.7 & 7.6 & 8.3 & 7.9 & 3.6 & 3.4 \\
\hline
\end{tabular}

be seen in the poorer vigour of growth in acidified formetanate treatment compared with that with formetanate alone.

Field trials. (Table 4). The $\mathrm{pH}$-value of spray liquid did not affect the amount of injury caused by $C$. concinna. The incidence of injury was very heavy. There were also no significant differences between acidified and neutral sprays in the effect on either L. rugulipennis or Piesma maculatum. The incidence of damage of these two species was very slight. Only $4 \%$ of the seedlings were injured by $L$. rugulipennis and even these $p^{l}$ ants were injured later than at cotyledon stage. The mean number of piesmid eggs in the control was 0.1 per seedling.

Neither root nor top yield was significantly affected by the $\mathrm{pH}$ of the spray liquid. ( $\mathrm{F}=0.05$ for root yield, 0.33 for top yield).

In 1974, when the differences in $\mathrm{pH}$ between acidified and neutral spray liquids were only slight, there were likewise no significant differences in the respective figures.

Table 4. Injury caused by L. rugulipennis and C. concinna and number of piesmid eggs in sugar beet seedlings treated with acidified (a) and non acidified (n) spray liquids. Field experiments 1973.

\begin{tabular}{|c|c|c|c|c|}
\hline & & $\begin{array}{l}\text { Injury ca } \\
\text { Chaetocnema } \\
\text { concinna } \\
\text { No. of feeding } \\
\text { holes per plant }\end{array}$ & $\begin{array}{l}\text { by } \\
\text { Lygus } \\
\text { regulipennis } \\
\%\end{array}$ & $\begin{array}{c}\text { Number of } \\
\text { eggs of } \\
\text { Piesma maculatum } \\
\text { per } 50 \text { plant }\end{array}$ \\
\hline \multirow{2}{*}{ Control ......................... } & a & 49 & 4.1 & 5.7 \\
\hline & $\mathrm{n}$ & 48 & 4.5 & 4.3 \\
\hline \multirow{2}{*}{ Dimethoate .................. } & a & 38 & 4.8 & 4.3 \\
\hline & $\mathrm{n}$ & 43 & 4.5 & 4.7 \\
\hline \multirow{2}{*}{ Formetanate .................. } & a & 41 & 4.2 & 1.7 \\
\hline & $\mathrm{n}$ & 44 & 3.5 & 2.2 \\
\hline \multirow{2}{*}{ Methidathion ................. } & a & 46 & 4.3 & 4.5 \\
\hline & $\mathrm{n}$ & 44 & 4.3 & 4.2 \\
\hline $\mathrm{F}$ pH $\ldots \ldots \ldots \ldots \ldots \ldots \ldots \ldots \ldots \ldots \ldots$ & & 0.002 & 1.79 & 0.24 \\
\hline Insecticide $\mathrm{x}$ pH & & 0.30 & 0.57 & 0.66 \\
\hline
\end{tabular}


Acidification did thus not improve the efficiency of insecticides known to be rather quickly inactivated in alkaline spray waters as was the case in studies made by JoHANSEN and Eves (1972). The insecticides were, however, different in these studies as also were the acidifiers. Perhaps the adding of some buffer in solutions used in the present study might have had some effect on the results. The spray waters used by JoHANSEN and EvEs (1972) were more buffered judging by the $\mathrm{NaOH}$ requirement of the solutions. On the other hand the slight differences between the effect of acidified and non acidified spray liquids in the present study seemed to point in favour of non acidified solutions.

Acknowledgements. This work was principally carried out at the Department of Pest Investigation of the Agricultural Research Centre, Tikkurila. I wish to express my sincere thanks to Mr. T. Tares, M. Ph. for his quidance in preparing the acidified sprays.

\section{REFERENCES}

Johansen, C. \& Eves, J. 1972. Acidified sprays, pollinator safety, and integrated pest control on alfalfa grown for seed. J. Econ. Ent. 65: 546-551.

VAris, A.-L. 1974. Piesma maculatum Lap. as a pest on sugar beet in Finland. Ann. Agric. Fenn. 12: 105-112.

- -1975 . Lindane seed dressing and dimethoate spraying in pest control of sugar-beet seedlings. Ann. Agric. Fenn. 14: 193-202.

VARIS, A.-L. \& RAUtAPÄÄ, J. 1976. Chemical control of sugar-beet pests in Finland: efficiency and economic return. Ann. Agric. Fenn. 15: 138-145.

Käsikirjoitus saapunut 20.7.1976.

\section{SELOSTUS}

\section{Ruiskutusnesteen pH:n vaikutus eräiden insektisidien tehoon sokerijuurikkaan taimia vioittavien tuholaisten torjunnassa.}

AnNa-LIISA VARIS

Helsingin yliopisto, Maatalous- ja metsäeläintieteen laitos

Jotkut tuhoeläintorjunta-aineet, kuten esimerkiksi sokerijuurikkaan taimien tuholaistorjuntaan yleisesti käytetty dimetoaatti ovat huomattavasti pysyvämpiä happamessa kuin alkaalisessa liuoksessa. Tässä tutkimuksessa pyrittiin selvittämään voitaisiinko sokerijuurikkaan taimien tuholaistorjunnassa ruiskutusten tehoa parantaa tekemällä ruiskutusneste happameksi. Tutkitut torjunta-aineet olivat $40 \%:$ n dimetoaattiruiskute, $50 \%$ :n formetanaattiruiskutejauhe ja $40 \%: n$ metidationiruiskute.

Ruiskutteet sekoitettiin vesijohtoveteen. Happamuuden aikaansaamiseksi lisättiin liuokseen 0.1 M fosforihappoa kunnes nesteen $\mathrm{pH}$ oli 4. Laboratoriokokeissa ruukuissa kasvavat sokerijuurikkaan taimet käsiteltiin insektisideillä. Kun ne olivat ruiskutuksesta kuivuneet, käsittelemättömiä luteita päästettiin ruukkujen päälle asetettuihin PVC-lieriöihin. Näistä tarkastettiin luteiden kuolleisuus ja taimien vioittuminen. Kenttäkokeista tarkastettiin peltoluteen ja kirppojen vioitus sekä juurikasluteen munien luku. Kasvuston rehevyys arvioitiin ruuduttain. Koe korjattiin syksyllä normaaliin aikaan ja sato punnittiin.

Ruiskutusnesteiden $\mathrm{pH}: \mathrm{n}$ alentaminen ei parantanut tehoa luteisiin eikä kirppoihin. Se ei myöskään vaikuttanut juuri- eikă naattisadon mäăräăn. 